таку особистість, яка здатна реалізувати свій творчий потенціал, тобто відбутися як творча особистість.

Цей аспект проблеми потребує подальшого дослідження за такими напрямками:

- реалізація методу експертних оцінок системи творчих можливостей, що визначає структуру творчої особистості;

- виявлення набору характерологічних рис особистості, які $\epsilon$ значущими для становлення творчої особистості в умовах компетентнісної освіти та забезпечення діагностування рівня їх сформованості.

\title{
Література
}

1. Андреев В. И. Диалектика воспитания и самовоспитания творческой личности / В. И. Андреев. - Казань : Изд-во Казанского университета, 1988. - 228 с. 2. Кичук Н. В. Формування творчої особистості вчителя / Н. В. Кичук. - Київ : Либідь, 1991. - 96 с. 3. Лук А. Н. Психология творчества / А. Н. Лук. - Москва: Наука, 1978. -127 с. 4. Педагогічна оцінка рівня сформованості творчих можливостей учнів (метод експертних оцінок): [науково-метод. посіб. для студентів]/ упорядник Кисільова-Біла В. П. - Кривий Ріг : КПІ ДВНЗ «КНУ», 2012. - 83 с. 5. Пономарев Я. А. Психология творчества и педагогика / Я. А. Пономарев. - Москва : Педагогика, 1976. - 280 с. б. Поташник М. М. Педагогическое творчество: проблемы развития и опыт: [пособие для учителя]/ М. М. Поташник. - Київ : Рад. шк., 1983.-187 c. 7. Равен Дж. Компетентность в современном обществе: выявление, развитие и реализация / Дж. Равен; [перев. с англ.].Москва : Кошто-Центр, 2002. - 396 с. 8. Савченко О. Я. Компетентнісний підхід як чинник модернізації початкової освіти / О. Я. Савченко // Наука і освіта : науково-практичний журнал Південного наукового центру НАПН України. Педагогіка. - 2011. - № 4. - С. 13-16. 9. Сисоєва С. О. Педагогічна творчість: [монографія] / С. О. Сисоєва. - Харків, Київ : Каравела, 1998. - 150 с. 10. Сухомлинский В. А. Педагогические сочинения: в 3-Х т. - Т. 1. / сост. О. С. Богданова, В. З. Смаль. - Москва : Педагогика, 1979. - 560 с.

УДК $371.134: 33$

Оксана Мироненко

\section{ТВОРЧА ОСОБИСТІСТЬ ЯК ЦІЛІСНА ЛЮДСЬКА ІНДИВІДУАЛЬНІСТЬ В УМОВАХ КОМПЕТЕНТНІСНОЇ ОСВІТИ}

Мироненко О. В. Творча особистість як цілісна людська індивідуальність в умовах компетентнісної освіти.

У статті аналізуються, порівнюються та зіставляються такі наукові феномени, як «компетентність», «компетенція», «комунікативна компетенція», «мовна компетенція», уточнюється сутність використовуваних дефініцій у контексті компетентнісного підходу. Автор конкретизує творчу особистість як цілісну людську індивідуальність.

Ключові слова: творча особистість, цілісна людська індивідуальність, компетентнісний підхід, компетентність, компетенція, комунікативна компетенція, мовна компетенція.

Мироненко О. В. Творческая личность как целостная человеческая индивидуальность в условиях компетентностного образования.

В статье анализируются, сравниваются и сопоставляются такие научные феномены, как «компетентность», «компетенция», «коммуникативная компетенция», «языковая 
компетенция», уточняется суть используемых дефиниций в контексте компетентностного подхода. Автор конкретизирует творческую личность как целостную человеческую индивидуальность.

Ключевые слова: творческая личность, целостная человеческая индивидуальность, компетентностный подход, компетентность, компетенция, коммуникативная компетенция, языковая компетенция.

Mironenko O. V. Creative personality as a holistic human individuality in a competencebased education.

This article analyzes, compares and matches such scientific phenomena as «competency», «competence», «communicative competence», «linguistic competence», the meaning of the used definitions in the context of competence-based approach are defined. The author specifies a creative personality as a holistic human individuality.

Key words: creative personality, holistic human individuality, competence-based approach, competency, competence, communicative competence, linguistic competence.

Однією 3 актуальних проблем сучасної української системи освіти є творча особистість як цілісна людська індивідуальність. Безумовно, творча, або креативна, особистість характеризується передовсім такими особливостями, як здатність бачити проблеми, готовність розв'язувати їх та концентруватися на новому, прагнути бути неординарним, розвивати свої розумові здібності, володіти інформаційними технологіями.

Особливості формування творчої особистості висвітлювалися у розвідках таких науковців, як: Ю. Бабанський, Ф. Баррон, Д. Гарінгтон, Н. Кузьміна, О. Павлик, Я. Пономарьов, Г. Сіліна та інших.

Мета статmі-проаналізувати творчу особистість як цілісну людську індивідуальність в умовах компетентнісної освіти, скорегувати понятійну базу.

Огляд і аналіз наукової літератури надає змогу стверджувати, що творчість - це «діяльність людини, спрямована на створення духовних і матеріальних цінностей» [3, с. 1435], або «процес людської діяльності, що створює якісно нові матеріальні та духовні цінності» [8, с. 405].

Досліджуючи специфічні особливості творчості, Г. Альтштуллер та Н. Вертні визначити такі ії показники [1]:

1. Творчість є основою розвитку емпатійних здібностей, здатності розуміти точку зору іншої людини, формування непрагматичної ціннісно-світоглядної орієнтації особистості.

2. Творчість передбачає вихід за межі рольових установок особистості, вміння дистанціюватися від ситуації, готує умови для досягнення однієї з головних цілей розвитку людини - статусу творчої особистості, оскільки творчість $є$ виходом у сферу багатозначного, багатомірного, парадоксального, бісоціативного розуміння реальності та іiі опанування; творчість передбачає актуалізацію надситуативності як здатності суб'єкта виходити за межі однозначних конструкцій «зовнішньої доцільності».

3. Істоти, у яких розвинутий пошуковий механізм, що $є$ наріжним для процесу творчості, характеризуються мінімальною агресивністю щодо свого оточення та найчутливіші до закликів допомоги інших істот.

4. Творчість та альтруїзм позитивно взаємокорелюють та щільно пов'язані, що свідчить про відкритість творчої особистості світові. 
5. Творчість $є$ однією з цілей розвитку особистості та може бути пов'язаною з такими категоріями, як самоактуалізація, самовдосконалення, самоздійснення, самовираження.

6. Творчість є цілісним утворенням, вона не обмежується такими аспектами функціонування психіки людини, як образний, логічний, поведінковий та інші, а виявляється на всіх рівнях психічної активності людини.

7. Творчості притаманні синергетичні риси, тому творча людина виявляє феномен творчої багатомірності, коли окремий талант людини складається із суми її талантів.

8. Так звані творчі люди характеризуються гранично-біфукарційними, парадоксально-двоїстими, ембівалентними, взаємовиключаючими особливостями, наприклад, вони виявляють себе як одночасно екстраверти та інтроверти; вони скромні та горді одночасно; вони виявляють одночасно бунтарський дух та консерватизм.

Слід зазначити, що не вся діяльність особистостей має творчий характер. На думку Л. Яценко, творчій діяльності властиві такі характеристики [10]:

1. Творча діяльність $є$ способом буття людини у світі, вона $є$ похідною від історії і культури і повніше за все виражає соціальну сутність людини.

2. До творчості причетні не будь-які форми людської активності, а тільки цілеспрямована діяльність, остання протистоїть не окремим проявам несвідомого, а стихійному, мимовільному перебігу подій, що має місце у природі та історії.

3. Невід'ємним атрибутом творчості є свобода, що виникає в самій діяльності й виражається не тільки в контролі роботи людини над природними й соціальними процесами, але й у самоволодіння; свобода у творчості полягає в умінні підкоряти свої думки й дії поставлені меті й знаходити найефективніший спосіб просування до неї.

4. У творчій діяльності присутні компоненти трьох типів: продуктивні, репродуктивні й рутинні, що виражають різні підходи до культури, до соціальних передумов праці.

5. Продуктивні компоненти творчого процесу забезпечують його результату такі ознаки, як істотна новизна, соціальна значущість і досконалість виконання, які складають онтологічний, аксіологічний і естетичний аспекти творчого продукту.

6. Поряд 3 головними типами співвідношень продуктивних i репродуктивних компонентів, існують ще три модифікації нетворчої діяльності, у яких відсутня та або та група продуктивних дій: псевдо творчість, що імітує творчий пошук, антитворчість, позбавлена аксіологічного аспекту, і «творчість у собі».

Аналізуючи творчу особистість, Х. Зіверт визначив ऑii особливості [4]: 1. Інтелектуальний потенціал - гнучкість, швидкість, дивергентність, здатність до наслідування. 2. Допитливість - внутрішня пізнавальна мотивація, відчуття нового. 3. Ініціатива - постійна активність і зайнятість, працелюбність, любов до труднощів. 4. Незалежність, самостійність, прагнення до самовираження. 5. Наполегливість, відданість справі. 6. Оригінальність, творчість: прагнення до творчих задач та занять, винахідливість. 7. Ерудиція, самореалізація.

Творча особистість повинна бути пройнята елементами нового, вдосконалювати та збагачувати свої знання, розвивати власні здібності. Зазначимо, що творча особистість, окрім володіння мовою, повинна використовувати ії в конкретному середовищі чи ситуації, тобто оперувати комунікативною компетенцією.

Успіх комунікації значною мірою залежить від компетенції адресата і адресанта. Виокремлюють чотири їі типи [2, с. 122].

- предметна компетенція - розуміння предметного (феноменального) світу, тобто 
його складників, їхніх системних та структурних зв'язків, функцій, тенденцій розвитку і змін тощо; це орієнтація людини у фізичному світі, без якої неможлива будь-яка комунікація;

- культурна компетенція - орієнтація в базових елементах культури, крізь які усвідомлюється предметний світ носіями мови. На думку деяких дослідників, культура, у межах якої відбувалась соціалізація особистості, визначає спосіб пізнання світу й орієнтації в ньому.

Предметна і культурна компетенції - об’єкт вивчення різних наук, зокрема філософії, когнітології, психології, культурології та інших, тобто фактично нелінгвістичні поняття;

- мовна компетенція - володіння засобами мови, тобто одиницями і категоріями всіх iii рівнів, стилістичними засобами, законами їх використання тощо;

- комунікативна компетенція - навички використання мови в конкретному контексті й ситуації спілкування; уміння зорієнтуватись у співбесіднику, ефективно впливати на нього.

Загальновідомо, що вагомим складником комунікативної компетенції $\epsilon$ мовна компетенція. Мовна компетенція складається з лексичної, граматичної, семантичної, фонологічної, орфографічної, орфоепічної та пунктуаційної компетенції.

Лексична компетенція виявляється в «оволодінні лексичними засобами сучасної української літературної мови і вмінні користуватися ними» [5, с. 13-14]. Використання різної лексики залежить від ситуації, у якій перебуває творча особистість. Вона може оперувати як загальновживаною лексикою, так і словами іншомовного походження, залежно від міри володіння словниковим запасом.

Граматична компетенція - це «знання i вміння користуватися граматичними ресурсами української мови (словотвірні одиниці, способи словотворення, морфологічні одиниці, категорії і форми, синтаксичні одиниці й категорії), що необхідні для розуміння i продукування текстів у різних сферах» [5, с. 14].

Семантична компетенція - це «здатність комуніканта усвідомлювати й контролювати організацію змісту» [5, с. 14]. Вона об’єднується у розвиток мовленнєвої комунікативної компетенції, оскільки питання змісту має центральне місце в комунікації.

Фонологічна й орфоепічна компетенції пов’язані із знанням «звукових засобів сучасної літературної мови, вміння мовця ними користуватися» [5, с. 14]. Ці види компетенції характеризуються наданням мови звукового образу та правильної звукової репрезентації мовлення.

Орфографічна компетенція виявляється в «оволодінні системою правил, що визначають правопис слів згідно 3 усталеними нормами, та вмінні їх застосовувати» [5, с. 14].

Пунктуаційна компетенція характеризується «логічним інтонаційним членуванням мовного потоку та забезпечує легке сприймання і розуміння писемного тексту» [5, с. 14].

Мовленнєва компетенція полягає у здатності застосовувати мовленнєві вміння в конкретній ситуації творчою особистістю.

Так, досліджуючи дидактичні умови формування творчої особистості молодших школярів, О. Павлик, спираючись на думку Д. Романовської, стверджує, що психологопедагогічні умови розвитку творчої особистості школярів $\epsilon$ такими: педагогічне стимулювання, застосування психолого-педагогічних технологій, системність мовленнєвої роботи з учнями в умовах творчо-розвивального середовища [6, с. 115].

Педагогічне стимулювання характеризується комунікативною взаємодією учня i вчителя, розвиваються самостійність, емоційна образність, активність, ініціативність творчої особистості як цілісної людської індивідуальності. 
Застосування психолого-педагогічних технологій виявляється насамперед у вмінні мовця залежно від вікової групи передавати фонові знання та набувати нових умінь та навичок на основі побаченого, пережитого. Залучати до творчого процесу раціональний та чуттєвий досвід, намагатися повно відтворювати картини буття.

Системність мовленнєвої роботи з учнями в умовах творчо-розвивального середовища полягає в постійній роботі комунікантів над розвитком творчих здібностей. Через різного роду емоції реципієнт висловлює свої власні почуття, експресії. Творче середовище завжди сприяє кращому засвоєнню нового та розвиває мовно-мовленнєві компетенції.

Творча особистість повинна вміло оперувати мовною, предметною, культурною та мовленнєвою компетенціями, оскільки компетенція $є$ «здібністю виконувати будь-яке завдання, робити щось» [7, с. 173], що тісно пов'язано 3 компетентностями, де такі компетентності, як «поінформованість, обізнаність» $[3$, с. 560] є показниками цілісної людської індивідуальності в умовах сучасної освіти.

Творча особистість повинна вміти інтегрувати умови спілкування 3 мовною ситуацією, добирати мовні засоби відповідно до ролі мовця в навколишньому середовищі, розвивати свої мовно-мовленнєві компетенції та реалізовувати їх в умовах компетентнісної освіти.

\section{Література}

1. Альтштуллер Г. С. Как стать гением: жизненная стратегия творческой личности / Г. С. Альтштуллер, Н. М. Вертни. - Минск : Беларусь, 1994. - 479 с. 2. Бацевич Ф. С. Онови комунікативної лінгвістики: [підручник] / Ф. С. Бацевич. - Київ : Академія, 2004. - 344 с. 3. Великий тлумачний словник сучасної української мови / уклад. і голов. ред. В. Т. Бусел. Київ-Ірпінь : ВТФ «Перун», 2009. - 1736 с. 4. Зиверт Х. Тестирование личности / Х. Зиверт; [пер. с немец.]. - Москва : АО Интерэксперт, 1997. - 198 с. 5. Мацько Л. І. Культура української фахової мови / Л. І. Мацько, Л. В. Кравець. - Київ : Академія, 2007, - 360 с. 6. Павлик О. А. Дидактичні умови формування творчої особистості молодшого школяра на уроках української мови як другої / О. А. Павлик // Педагогічні науки. Випуск 67. Херсон : ХДУ, 2015. - С. 113-118. 7. Психологія мовлення і психолінгвістика: [навч. посіб. для студтів вищих навч. закладів]/ за ред. Л. О. Калмикової.- Київ: Переяслав-Хмельницький педагогічний інститут, 2008. - 235 с. 8. Философский словарь / под ред. М. М. Розенталя. Москва : Политиздат, - 1975. - 496 с. 9. Яковлева Е. Л. Психология развития творческого потенциала личности: [учеб. пособие] / Е. Л. Яковлева. - Москва : Флинта, 1997. - 287 с. 10. Яценко Л. В. Порождающие факторы творчества / Л. В. Яценко // Диалектика творческой деятельности. - Воронеж : Изд-во Воронежского университета, 1999. - 141 с.

Лиана Порохня

\section{ОБОСНОВАНИЕ ТЕХНОЛОГИИ ФОРМИРОВАНИЯ ГОТОВНОСТИ БУДУЩИХ УЧИТЕЛЕЙ К ПРЕДУПРЕЖДЕНИЮ И РАЗРЕШЕНИЮ КОНФЛИКТНЫХ СИТУАЦИЙ}

Порохня Л. А. Обгрунтування технології формування готовності майбутніх учителів до попередження і розв'язання конфліктних ситуацій.

У статті обгрунтовано технологію формування готовності майбутніх учителів до попередження і розв'язання конфліктних ситуацій. Виокремлено та схарактеризовано етапи означеної технології: мотиваційно-ціннісний, змістовно-операційний, особистісно- 